\title{
An Examination of Empathic Tendency, Self-regulation and Self-efficacy as Predictors of Conflict Resolution Skills in Adolescents
}

\author{
Fulya Türk \\ Department of Guidance and Psychological Counseling, Faculty of Education, Gaziantep University, Gaziantep, Turkey
}

Copyright $(2018$ by authors, all rights reserved. Authors agree that this article remains permanently open access under the terms of the Creative Commons Attribution License 4.0 International License

\begin{abstract}
The aim of this study is to examine empathic tendency, self-regulation abilities and self-efficacy perceptions in adolescents as predictors of conflict resolution skills. The sample of this study consists of 391 students from 9th and 10th classes of a high school in Kahramanmaras province. In the study, the Conflict Resolution Scale, KA-SI Empathic Tendency Scale, General Self-efficacy Scale, and Self-regulation Scale were used as data collection tools. Multiple regression analysis was used for the analysis of the data. According to results of the study, it was found that empathic tendency levels, self-regulation skills and self-efficacy perceptions of adolescents predicted their conflict resolution skills significantly. When the relative importance order of the predictor variables on the conflict resolution skills is examined, it is seen that the empathy variable is the most efficient predicting variable followed by self-regulation and self-efficacy. Besides, it was concluded that empathy was in the mediator in the relationship between conflict resolution skills and self-efficacy.
\end{abstract}

Keywords Conflict Resolution Skills, Empathic Tendency, Self-regulation, Self-efficacy, Adolescents

\section{Introduction}

In everyday life conflicts can inevitably occur in interpersonal relations. According to Deutsch (1973) conflict occurs when there are opposing actions. When an action is incompatible with another action, it prevents, blocks or defeats that activity. Opposing actions can occur between an individual, two or more individuals, or between two or more groups [15]. Bodine, Crawford, and Schrumpf emphasize the fact that conflict is a natural and indispensable part of life, and that when understood correctly it is an opportunity for learning and creativity [8].
People can experience conflict due to limited resources in their lives, lack of basic psychological needs, or having different values, beliefs and attitudes [41]. Because every individual is unique, all differences can cause conflict and it may not be possible to prevent it. What needs to be done at that point is to be able to solve the conflict in constructive ways. Constructive conflict resolution skills are effective in establishing successful, constructive relationships and managing interpersonal relationships [27]. In addition, they provide opportunities to learn effective communication skills, and help individuals increase their self-worth and quality of life [32]. In addition, constructive conflict resolution skills contribute to the development of individuals' anger management and empathy skills [50] and the development of problem-solving and leadership skills and self-esteem [33]. Besides, students with positive conflict resolution skills are less vulnerable to peer pressure and violence [34]. They also influence the prosocial behavior of other individuals [28]. The ability to manage conflict in a constructive manner is an important element of psychological well-being and harmony [25]. Destructive management of conflicts can lead to reduced self-esteem, increased social exclusion, and behavioral problems among children. On the other hand, constructive conflict resolution skills increase their psychological well-being, self-esteem, self-regulation and psychological endurance. This development in interpersonal relationships contributes to fewer feelings of anxiety and depression, the development of positive emotions, and the development of well-being [25].

During adolescence, the individual experiences a confluence of conflicting roles while trying to find his or her own identity [19]. Adolescents going through this phase may experience conflict situations during the process of gaining independence from their parents and other adults to establish their own identity [22]. For adolescents, friendship becomes more important in interpersonal 
relationships, and they spend most of their time in peer groups [40]. In adolescents, conflict often arises with families rather than with siblings or peers. This is because in terms of personal development, individual autonomy is gained in this period [39]. At this stage in their lives where peer relations are important, how they manage their conflict with their friends also seems to be an important factor. This is due to the fact that adolescents have difficulties in attaining their wishes and goals when they manage their conflicts in a destructive way, and this may also lead them to have difficulties with peer relations, which are very important for them. For this reason, it is thought that conflict resolution skills are important in enabling adolescents to develop a healthy personality and identity, as with all individuals.

Another important skill with a key role in interpersonal relationships is empathy. Empathy is the process during which a person looks at events from another person's point of view by putting him/herself in the place of another, understanding that person's feelings and thoughts correctly, and conveying this to him/her [16]. Empathy has a special and decisive role in the resolution of conflicts between people. Understanding how the other feels and thinks is a very important step for the constructive and peaceful resolution of the conflict. Understanding the point of view of the other side and stepping into their shoes positively affects the way the individual perceives the conflict. Dökmen emphasized that empathic understanding brings people closer to each other and facilitates communication [16]. According to Türnüklü, in the process of conflict resolution, it is difficult for a problem to be resolved in a constructive way without understanding the other person's feelings, emotions and their explicit and implicit causes [49]. Similarly, Johnson and Johnson emphasized the importance of understanding the other person's perspective in the negotiation process [26].

According to Wied, Branje and Meeus, empathy improves communication and helps people become successful at resolving interpersonal conflicts in long-term relationships [52]. In the event of a conflict, understanding the point of view of the other person will help to better understand the situation in which the other person finds themselves. This in turn prevents destructive behavior and facilitates constructive behavior. Investigators have found that high empathic tendencies are related to successful conflict management. Adolescents who base their friendship on trust and sincerity during puberty are more successful at understanding other people's perspectives, the point of view of the other; that is, developing empathy. However, possessiveness and jealousy may still be seen in their relationships with others [39].

Self-regulation is a complex tendency, defined in many different ways. Self-regulation is defined as the ability of a person to initiate or stop activities according to different circumstances, to manage the duration of verbal and motor actions in educational and social settings, as well as their intensity and frequency, to postpone behavior when deemed fit for purpose, and to demonstrate socially appropriate behavior without external supervision [31].

The literature on self-regulation focuses on two categories, namely emotional and behavioral control. Emotional control is the ability to promote, reduce, maintain, and prevent emotional stimulation in order to achieve one's goals, which also includes the ability to focus one's attention and adjust it as needed [17]. Behavioral supervision is the ability to postpone satisfaction and delay instant gratification to achieve better results in the future, and to demonstrate resistance to this self-imposed obstacle [48].

Self-regulation is related to emotions, postponement of satisfaction, moral development, cohesion, social competence, empathy, cognitive and academic performance [18]. Self-regulation is reported to have important effects on areas such as mental health, inter-personal relationships, and academic performance in children, adolescents and adults. In addition, self-regulation is associated with social skills and constructive peer relationships [17].

Self-regulation encourages individuals to participate in decisions about their own lives when given the opportunity. The responsibility of being involved in the decision-making process leads to self-discipline and to being responsible for one's own behavior, which is essentially what self-regulation is [25].

Interpersonal conflicts are often complicated. This is because, in the conflict process, a person's own goals are positively or negatively related to the goals of the other person. Emotions are intense during the conflict process and there is a tendency to act with destructive impulsiveness. Although people in a conflict may try to control their emotions, such as intense anger and fury, they often cannot prevent themselves from doing what they will later regret. Thus, in such an intense conflict situation, controlling negative emotions, namely assuming self-control, plays an important role in a successful conflict resolution process [37]. For this reason, it is thought that the relationship between conflict resolution skills and self-regulation skills are related to whether a conflict resolution process is constructive or destructive.

Self-efficacy is defined as the perceived capacity of a person to learn and succeed [52]. According to Schunk and Pajares, self- efficacy has a strong influence on a person's motivation, their ability to succeed, and self-esteem. This is due to the fact that people tend to choose the jobs and actions which they believe they can complete. If they do not believe that they will get what they want, they are less motivated [42]. While self- efficacy is a concept that affects many areas, this study emphasizes the fact that selfefficacy's most important social effect on adolescents, in terms of interpersonal relationships and conflicts, are 
friends and peer relationships. This is because the influence of peers among adolescents is very strong. Peer groups are important in the socialization process. Adolescents choose their friends and friend groups on the basis of similarity. Perceived similarity increases the peer effect. Peer influence also affects self- efficacy. This is due to the fact that adolescents face many tasks with which they are unfamiliar and have little to rely upon other than their friends' behavior to measure their self-efficacy [43]. According to social learning theory as described by Balkıs, Duru and Buluş, a person's self-efficacy is related to two domains. A person needs to have the necessary knowledge and skills and develop appropriate behaviors in the area where he/she wants to be successful [4]. Hence, if a person has the belief that he/she can solve his/her conflicts with knowledge and skill without resorting to violence he/she tends to be less aggressive. In other words, one's perception of self- efficacy is important in that regard. From the point of view of the investigators, when an adolescent with a high sense of self- efficacy believes that he/she can resolve conflicts, it suggests that he/she will be more inclined to use his/her constructive and socially positive skills. A high sense of self-efficacy is also associated with increased satisfaction in the social relationships that will affect one's life satisfaction [5]. For this reason, the satisfaction obtained by the successful execution of relations in their social life may be effective in increasing a person's sense of self-efficacy [36].

This study intends to examine empathic tendency, self-regulation abilities and self- efficacy perceptions as a predictor of conflict resolution skills. When the related literature is examined, it can be seen that Animasahun investigated the power of emotional intelligence, mental intelligence, self-efficacy and creativity skills in predicting conflict resolving behaviors. According to the results of the study, four independent variables predict conflict resolution behaviors and emotional intelligence is the most important contributor when other variables are controlled [2]. Rehber and Atıcı examined conflict resolution behaviors according to the empathy tendency levels of elementary school second graders. According to this, students with low empathic tendencies used aggression more, whereas students with high empathic tendencies used their problem solving skills more [38]. Alexander examined the conflict resolution strategies and empathy skills that adolescents use in interactions with their parents and peers. In this study, a moderate and meaningful relationship was found between compromise, looking at things from a different perspective and empathic reaction in conflict resolution methods [1]. In their study on empathy and social intelligence, Björkqvist, Österman and Kaukiainen found that empathy reduced aggression, while they also found that social intelligence was related to conflict resolution strategies when included in the study without controlling empathy [7]. Wied, Branje and Meeus examined the role of empathy in the process of adolescents' conflict resolution in interactions with friends of the same sex. According to this study, adolescents with high empathy skills are better at managing conflict situations [52].

Syna Desylvanya and Eizen investigated the role of general and social self- efficacy in group conflicts among volunteers in business community service centers. According to this study, general self- efficacy and group identity were predictors of the strategy of domination, while social self-efficacy was the predictor of the strategy of reconciliation [44]. Vera, Shin, Montgomery, Mildner, and Speight examined the relationship between selfefficacy, self-control, and hope levels as predictors of adolescent conflict resolution styles. According to the results of the study, self- efficacy and self-regulation were found to have a meaningful role in the prediction of adolescents' conflict resolution styles [51]. Harma examined parental control behaviors and the effects of family conflicts on adolescents' self-regulation skills and compliance. Domestic conflicts were found to be predictors of adolescents' self-regulation skills [24]. In addition, Erözkan found that the attachment styles of high school students as well as their communication and problem-solving skills were predictors of their style for interpersonal interactions [20]. Likewise, Firıncı Kodaz stated that the constructive conflict-solving skills of vocational education students with high level social skills were also high [21]. Apart from the above, the relationship between conflict resolution skills and personality traits [6], self-perception and control focus [45], problem-solving, anger and aggression levels [14,23], social support and life satisfaction [9] and social gender roles [12] has been examined. This study, on the other hand, examines adolescents' conflict-solving skills in relation to empathic tendency, self-regulation skills and self- efficacy perceptions, and the ability of these variables to predict their conflict resolution skills. Although these variables were studied separately in different studies, there is no study in the literature evaluating the co-relation of these variables altogether. For this reason, it is thought that this study will contribute to the literature on conflict resolution and provide important insight for future studies and practices.

\section{Materials and Methods}

\subsection{Experimental Design}

This study used the relational screening model to determine to what extent the empathic tendencies, self-regulation and self-regulation levels of adolescents are predictors of their conflict resolution skills. A relational study examines the relationship between two or more variables without any intervention [11]. A diagram 
of the study's model is given in Figure 1:

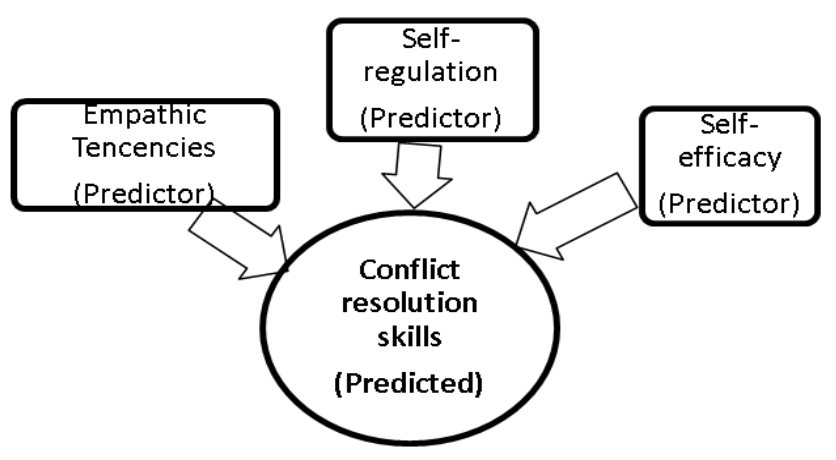

Figure 1. Experimental Design

When Figure 1 is examined, it is seen that the study was modeled to investigate how the predictor variables (empathy, self-regulation, and self-efficacy) affect the predicted variable (conflict resolution).

\subsection{Study Population and Sample}

The study population comprised of 9th and 10th grade high school students from the province of Kahramanmaraş. In this study, 391 students from 9th and 10th grades in a general high school in Kahramanmaraş province were determined as the study sample by using a targeted sampling method. Descriptive statistics for the sample are presented in Table 1.

Table 1. Distribution of the sample by sex and class level

\begin{tabular}{|c|c|c|c|c|}
\hline & & \multicolumn{2}{|c|}{ Grade Level } & \multirow{2}{*}{ Total } \\
\hline & & 9.th & 10.th & \\
\hline \multirow{2}{*}{ Sex } & Girl & 117 & 92 & 209 \\
\hline & Boy & 115 & 67 & 182 \\
\hline \multicolumn{2}{|c|}{ Total } & 232 & 159 & 391 \\
\hline
\end{tabular}

\subsection{Data Collection Tools}

In this study, the Conflict Resolution Scale, KA-SI Empathic Tendency Scale, General Self-Efficacy Scale, and Self-Esteem Scale were used as data collection tools. The psychometric properties of the scales are given below.

\subsubsection{Conflict Resolution Scale}

Developed by McClellan, this scale was adapted to Turkish by Taştan in accordance with the skills that are sought to be instilled in high school students and the aims of the study. The scale is scored from 1-5. In terms of conflict resolving behavior, the scores are allocated on the following range of answers: (1) Almost Never Like Me, (2) Rarely Like Me; (3) Sometimes Like Me; (4) Mostly Like Me; (5) Almost Always Like Me. Items 1, 3, 4, 13, 18, 19, $22,24,26,27,31,32,33$ and 39 of the scale contain negative statements about conflict resolution behavior and the scoring is reversed. The reliability coefficients obtained by the test-retest method of the scale are $r=.78$ for the total sum of the scale, $r=.75$ for the constructive conflict resolution approach scores, and $\mathrm{r}=.74$ for the destructive conflict resolution approach [46].

\subsubsection{KA-SI Empathic Tendency Scale}

This scale was developed by Kaya and Siyez as a measurement tool particular to Turkish culture to measure the empathic tendencies of children and adolescents. The result of the validity and reliability study of the scale showed a difference between the outlook of the 3rd-5th graders and 6th-12th graders. For this reason, it was thought that it would be appropriate to prepare the scale as separate forms for children and adolescents. The KA-SI Adolescent Form consists of 17 items; 10 emotional and 7 cognitive. The scale is scored from 1-4 where 1 means "Not at all like me", 2 means "Somewhat like me", 3 means "Very like me" and 4 means "Totally like me". As there is no negative item in the scale, the score values of participant responses are collected in parallel with the responses. The emotional empathy subscale score, which is measured by totaling the scores of the responses given to 10 items measuring emotional empathy, the cognitive empathy subscale score obtained by totaling the scores of the responses given to the 7 items that measure cognitive empathy, and the total empathy tendency score obtained by totaling the two scores above, are obtained from the scale. The minimum score for the emotional empathy subscale is $10 \mathrm{x} 1=10$, the maximum score $10 \mathrm{x} 4=40$, the minimum score for the cognitive empathy subscale is $7 \times 1=7$, the maximum score $7 \times 4=28$, the minimum total empathic tendency score is $17 \times 1=17$, and the total emphatic tendency score is $17 \times 4=68$. Empathic tendency increases as the scores from the scale increase, and empathic tendency decreases as the scores decrease. The Cronbach's alpha internal consistency coefficients were 0.87 (KA-Si), .82 (Emotional empathy) and .82 (cognitive empathy). The test-retest reliability coefficients for the full scale KA-SI, Emotional Empathy and Cognitive Empathy were $.75, .73$, and .69 , respectively [30].

\subsubsection{General Self-Efficacy Scale}

The General Self-Efficacy Scale developed by Schwarzer and Jerusalem was translated into Turkish by Teközel. Consisting of 10 items this scale is a 4-point Likert-type scale in which expressions are used to evaluate how well an individual perceives him/ herself in coping with difficulties. The scale has the respondent choosing the suitable answer from the options of "Not at all true", "Slightly true", "Somewhat true" and "Completely true", which are respectively scored as 1 (one), 2 (two), 3 (three) and 4 (four). The highest score that can be obtained from the General Self-Efficacy Scale is 40 , and the lowest score is 10 . A high score indicates that the respondent has a good sense of self-efficacy. The 
Cronbach's alpha coefficient of the scale varied between .76 and .90 . In this study, the Cronbach's alpha coefficient for the Turkish sample group was .82 [47].

\subsubsection{Self-Regulation Scale}

This scale was developed by Moilanen to assess the self-regulation skills of adolescents. Available in formats for both adolescents and parents, the Self-Regulation Scale aims to evaluate the extent to which adolescents act upon, adjust, control, maintain and constrain their emotions, behaviors, thoughts and attention. The scale was translated into Turkish by Harma. In the exploratory factor analysis, two dimensions, namely success (18 items) and inadequacy (14 items), came to the fore with regards to self-regulation. The items pointing to efficacy in self-regulation are scored in the range of 1 (not like me at all) to 4 (very like me), while those pointing to inadequacy in self-regulation $(2,6$, $7,8,10,11,12,16,17,28,29,30,31,32)$ are scored in reverse. The items in the scale adapted for adults are the same as those used for adolescents, except that they are in the third person rather than second person ("If he/she really wants something, he/she wants to have it right now and not later" etc.) The cronbach alpha coefficient of the success subscale was .85 and inadequacy subscale was .80 [24]. In this study, the total score obtained from the scale is used.

\subsection{Data Collection}

The investigator interviewed the school psychological counselor for the purposes of the study. They also provided information about the scales used in the study. The scales were applied under the supervision of the school counselor during the students' lesson time. Applying the scales took about one lesson hour. The process of applying the scales to all 9th and 10th grade students was completed in about two weeks. It was also stated that the results of the scale could be shared later with students who wished to have them.

\subsection{Data Analysis}

Within the scope of the study, multiple regression analysis was used to determine to what extent the empathic tendencies, self-regulation and self-efficacy levels of adolescents are predictors of their conflict resolution skills. Multiple regression analysis is a type of analysis used to predict a dependent variable based on two or more independent variables (predictor variables) associated with the dependent variable [10]. The staged regression method, one of the multiple regression analysis methods, was used to determine the extent to which independent variables described the model. With this method, the investigator can examine the effect of variables determined within the scope of the study (other variables are considered as control variables) on the predictor variable [13]. In order to decide whether statistical methods are appropriate for the study data, it is first necessary to test the assumptions of the method. For this reason, the assumptions for the regression analysis were tested first. One of the assumptions of the analysis is that the dependent and independent variables must be continuous variables measured at least in the same interval scale and they should show normal distribution [10]. The central tendency measures and the skewness and kurtosis coefficients were examined and shown in Table 2 to check whether the predicting and predicted variables show normal distribution.

Table 2. Descriptive statistics of predicting and predicted variables

\begin{tabular}{|ccccc|}
\hline & $\begin{array}{c}\text { Conflict } \\
\text { Resolution }\end{array}$ & $\begin{array}{c}\text { Empathic } \\
\text { tendency }\end{array}$ & Self-efficacy & Self-regulation \\
\hline Mean & 3.4390 & 3.0403 & 3.0944 & 2.4642 \\
Median & 3.4500 & 3.0625 & 3.1000 & 2.4688 \\
Mode & 3,43 & 3.35 & 3,40 & 2.56 \\
$\begin{array}{c}\text { Skewness } \\
\text { coefficients } \\
\begin{array}{c}\text { Kurtosis } \\
\text { coefficients }\end{array}\end{array}$ & -.431 & -.456 & -.525 & -.177 \\
\hline
\end{tabular}

When Table 2 is examined, it is seen that the mean, median and mode values are close to each other and the skewness and kurtosis coefficients are close to 1 . Therefore, it can be said that the distribution does not show excessive deviation.

On the basis of assumptions from the multiple regression analysis, it was examined whether the relationship between the predictor variables and the predicted variables is linear. The scatter diagram was drawn for the control of this assumption and the graph of linearity was given in Graph 1. 


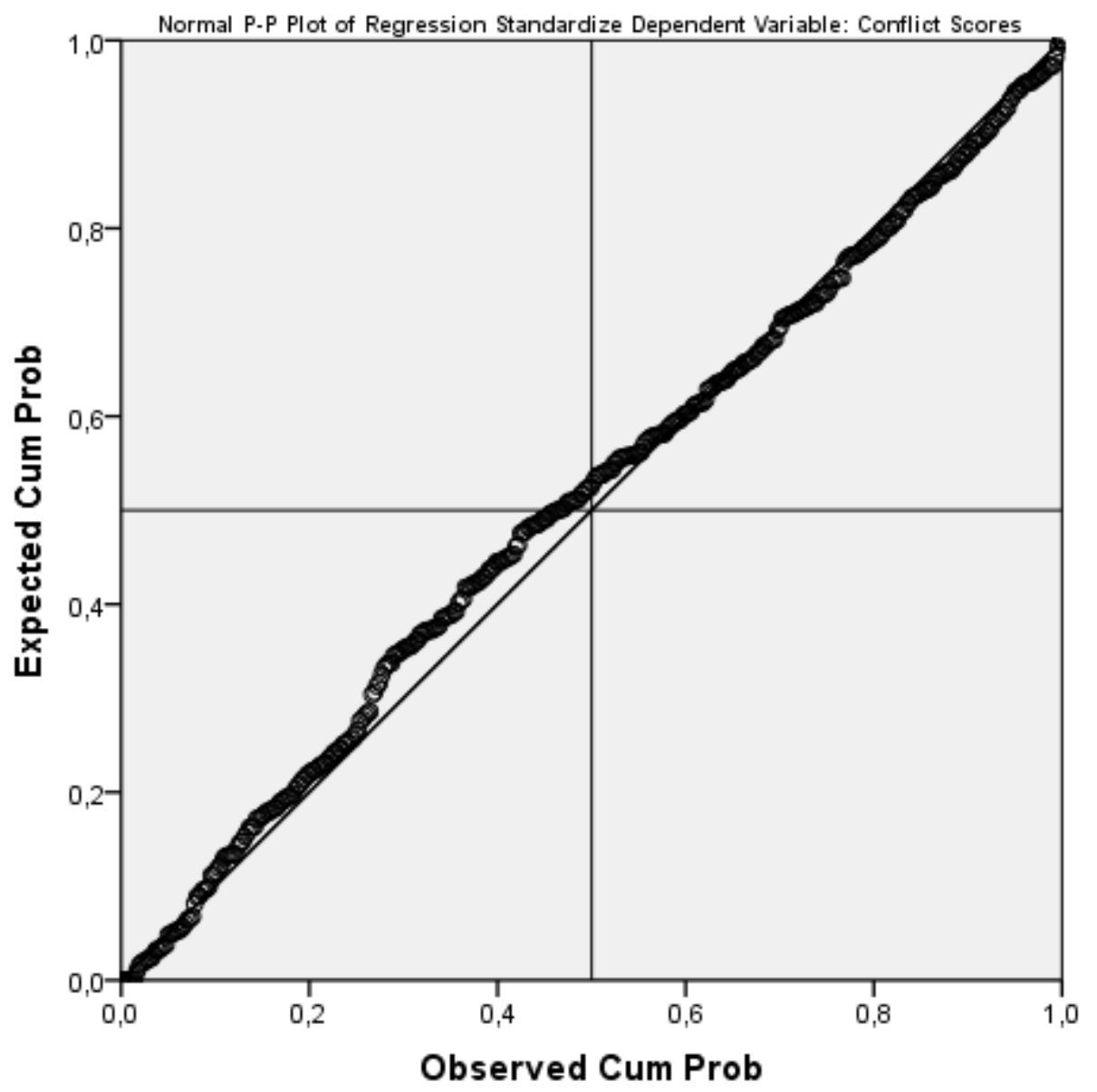

Graph 1. Linearity graph of the existing linear relationship

When Graph 1 is examined, it can be said that the scatter diagram generated for the standardized surplus values and the standardized predicted values defines a linear relationship. It can be argued that the normal distribution curves are close to normal.

It is expected that the predictor variables should not have a high degree of relationship among themselves [10], so that the regression analysis can give correct results. Correlations between the variables were examined to that. The relationship between the predictor variables ranged from 0.19 to 0.43 indicating that correlations were not high. In addition, the variance inflation factors (VIF) and tolerance values were examined to determine the correlation between the predictor variables and presented in Table 3.

Table 3. The variance inflation factors (VIF) and tolerance values for the predictor variables

\begin{tabular}{|ccc|}
\hline \multirow{2}{*}{ Variables } & \multicolumn{2}{c|}{ Multiple Correlation Statistics } \\
\cline { 2 - 3 } Self-regulation &, 812 & 1,232 \\
\cline { 2 - 3 } Empathic &, 961 & 1,040 \\
tendency &, 785 & 1,274 \\
Self-efficacy & & Variance Inflation Factors \\
\hline
\end{tabular}

Table 3, which contains the variance inflation factors
(VIF) and tolerance values for the predictor variables, is examined, it can be said that there is no multiple correlation, as the VIF values are smaller than 10 and the tolerance values are larger than 0.2 .

The Mahalanobis distances were calculated and evaluated with this value due to the fact that in the regression process the extreme values impaired the compliance of the existing regression equation with the theoretical model [13]. In the study, the independent variable of three, and the values of the Mahalanobis distance of 11.345 for $\mathrm{p}$ : 0.01 were deleted because they were extreme values. With the deletion of this data, the sample on which the regression analysis was to be performed fell to 391 .

\section{Results}

Multiple regressions were performed to determine the conflict resolution prediction capabilities of the self-regulation, self-efficacy and empathic tendency independent variables. Before the regression analysis, the relationship between the variables was examined by Pearson Product Moment Correlation Coefficient. Correlations of variables with each other and with conflict resolution skills are presented in Table 4. 
Table 4. Correlation between predictor and predicted variables

\begin{tabular}{|ccccc|}
\hline & $\begin{array}{c}\text { Conflict } \\
\text { resolution }\end{array}$ & $\begin{array}{c}\text { Empathic } \\
\text { tendency }\end{array}$ & Self-efficacy & Self-regulation \\
Conflict & 1 & $.445^{* *}$ & $.252^{* *}$ & $.340^{* *}$ \\
resolution & 1 & & $.197^{* *}$ & .077 \\
$\begin{array}{c}\text { Empathic } \\
\text { tendency }\end{array}$ & $.445^{* *}$ & 1 & 1 & $.434^{* *}$ \\
Self-efficacy & $.252^{* *}$ & $.197^{* * *}$ & 1 & 1 \\
Self-regulation & .340 & .077 & $.434^{* *}$ & 1 \\
$\mathrm{p}<0.01$ & & & &
\end{tabular}

As seen in Table 4, there is a medium level, positive and significant relationship between conflict resolution skills and empathic tendency levels $(\mathrm{r}=0.445, \mathrm{p}<.05)$. There is a medium level, positive and significant relationship between conflict resolution skills and self-regulation skills $(\mathrm{r}=0.340, \mathrm{p}<.05)$. Finally, there is a low level, positive and significant relationship between conflict resolution skills and self-efficacy perception $(\mathrm{r}=0.252, \mathrm{p}<.05)$. The regression analysis results are presented in Table 5.

Table 5. Hierarchical regression analysis results

\begin{tabular}{|c|c|c|c|c|c|c|c|c|c|c|}
\hline & \multirow{2}{*}{ Model } & \multicolumn{2}{|c|}{ Unstandardized Coefficients } & \multirow{2}{*}{$\frac{\text { Standardized Coefficients }}{\text { Beta }}$} & \multirow{2}{*}{$\mathrm{t}$} & \multirow{2}{*}{$\mathrm{p}$} & \multirow[b]{2}{*}{$\mathrm{R}$} & \multirow[b]{2}{*}{$\mathrm{R}^{2}$} & \multirow[b]{2}{*}{$\mathrm{F}$} & \multirow[b]{2}{*}{$\mathrm{p}$} \\
\hline & & B & Std. Error & & & & & & & \\
\hline \multirow{2}{*}{1} & Constant & 2.508 & .132 & & 19.026 & .000 & \multirow{2}{*}{0.340} & \multirow{2}{*}{0.116} & \multirow{2}{*}{50.931} & \multirow{2}{*}{0.000} \\
\hline & Self-regulation & .378 & 0.53 & .340 & 7.137 & .000 & & & & \\
\hline \multirow{3}{*}{2} & Constant & 2.353 & .146 & & 16.167 & .000 & \multirow{3}{*}{0.359} & \multirow{3}{*}{0.129} & \multirow{3}{*}{28.800} & \multirow{3}{*}{0.000} \\
\hline & Self-regulation & .316 & .058 & .284 & 5.407 & .000 & & & & \\
\hline & Self-efficacy & .100 & .041 & .129 & 2.452 & .015 & & & & \\
\hline \multirow{4}{*}{3} & Constant & 1.590 & .154 & & 10.337 & .000 & \multirow{4}{*}{0.542} & \multirow{4}{*}{0.293} & \multirow{4}{*}{53.688} & \multirow{4}{*}{0.000} \\
\hline & Self-regulation & .321 & .053 & .288 & 6.085 & .000 & & & & \\
\hline & Self-efficacy & .035 & .037 & .046 & .945 & .345 & & & & \\
\hline & Empathic tendency & .313 & .033 & .414 & 9.500 & .000 & & & & \\
\hline
\end{tabular}
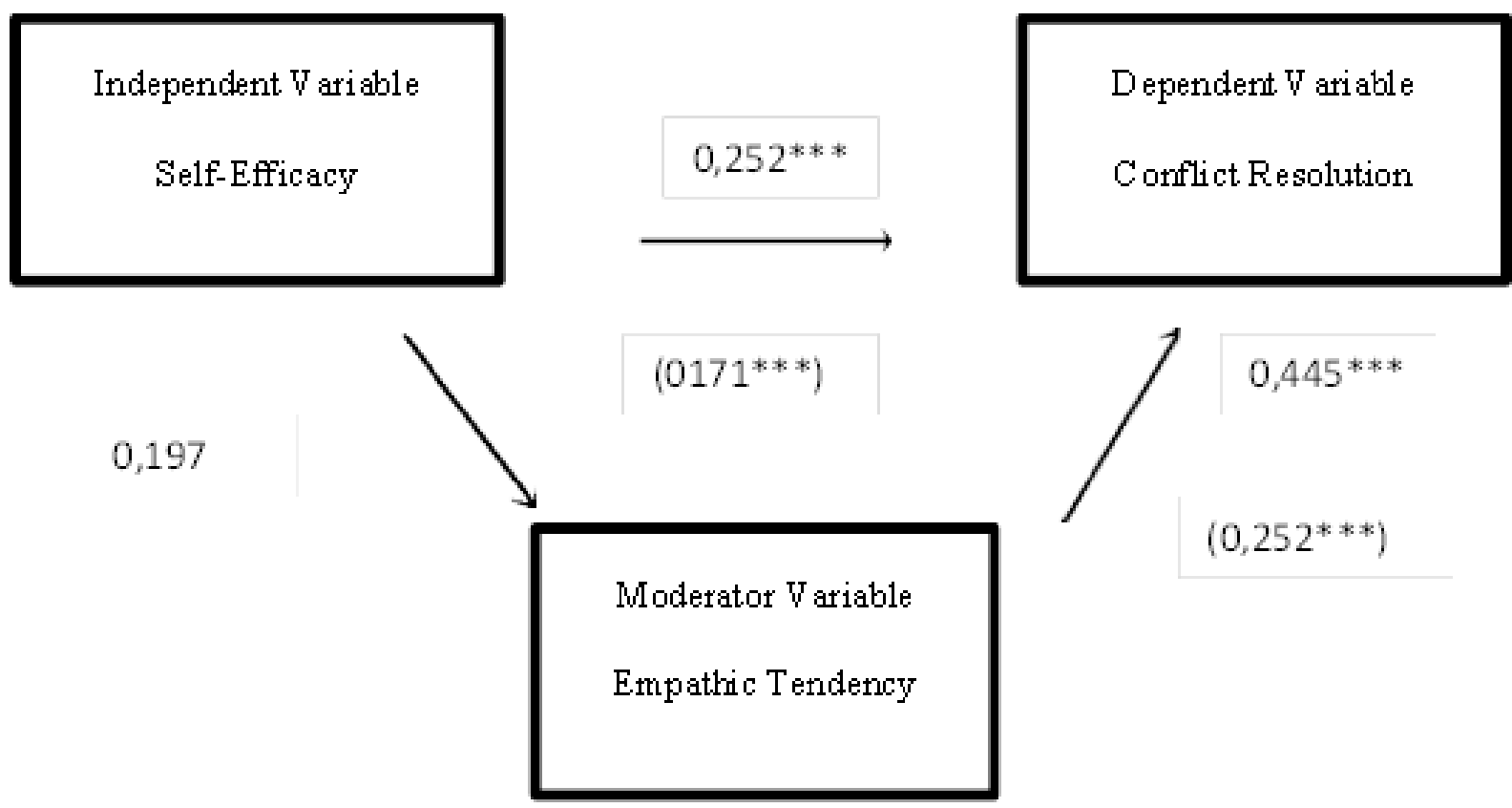

Figure 2. Intermediary effect and standardized beta coefficients $\left({ }^{*} \mathrm{p}<.05, * * \mathrm{p}<.01, * * * \mathrm{p}<.001\right)$ 
Since the $\mathrm{p}$ value is lower than 0.01 in the ANOVA table which tests the significance of the $\mathrm{R}$ in the regression model (predictor variables, the level of explaining its relationship with the predicted variable and thus the change in the predicted variable), it may be said that there is a significant relationship between the predicted variable and predictor variables. According to the result of the hierarchical multiple linear regression analyses, together the variables of self-regulation, self-efficacy and empathy show a significant relation with conflict resolution skills ( $\mathrm{F}$ $(3-385)=53.688, p<0.01) .29 .3 \%$ of conflict resolution skills are accounted for by these three variables. According to the standardized regression coefficients, when the relative importance order of the predictor variables on the conflict resolution skills is examined, it is seen that the empathy variable $(\beta=0.414)$ is the most efficient predictor variable followed by self-regulation $(\beta=0.288)$ and self-efficacy $(\beta=0.046)$. When the significance of the regression coefficients is examined, it is seen that self-efficacy $(p<0.01)$ and self-regulation $(p<0.01)$ are significant predictors. One remarkable aspect of the analysis was that after empathy was added to the model, the effect of self-efficacy on conflict resolution skills fell from $\beta=0.129$ to $\beta=0.046$. Once empathy is added to the model, self-efficacy ceases to be significant. The fact that self-efficacy level ceases to be a significant predictor variable when empathy is added to the model indicates that empathy may be the mediating variable. The effects of this intervention and the general pattern are shown in Figure 2.

The Sobel test was used to determine the significance of the mediation effect. The Sobel test was used by Jose with MedGraph-I program prepared and developed in Excel environment [29]. Sobel z-value was obtained as 1.689.053, $\mathrm{p}=0.09$. Therefore, since $\mathrm{p}$ value is significant in Sobel test, it was determined that empathic tendency has a full mediation effect. In other words, it may be stated that empathic tendency is a full mediator in the relationship between conflict resolution skills and self-efficacy.

\section{Discussion, Conclusions and Suggestions}

This study examined the relationship between empathic tendency, self-regulation and self-efficacy perception in adolescents as a predictor of their conflict resolution skills. According to study results, three independent variables explain $29 \%$ of conflict resolution skills. It was seen that there was a medium level, positive and significant relationship between conflict resolution skills and self-regulation skills, self-efficacy perceptions, empathic tendency levels of adolescents. The conducted regression analysis found that self-efficacy skills predicted conflict resolution skills significantly. Similarly, it was found that self-efficacy perceptions also predicted conflict resolution skills significantly. When empathic tendency is added to regression analysis finally, self-efficacy perceptions cease to be a significant predictor. Empathic tendency predicts conflict resolution skills significantly. Therefore, it is examined whether empathy has a mediating role in the relationship between self-efficacy perceptions and conflict resolution skills of adolescents and it is found that it is a full mediator. It is plausible to state that adolescents with a higher empathic tendency also have stronger constructive conflict resolution skills. Accordingly, it may be said that empathic tendency has a major role in conflict resolution skills of adolescents. Johnson and Johnson emphasized that it is very important to understand the other person's perspective in order to resolve a conflict constructively. Understanding perspectives improves communication and reduces misunderstandings, and it is very important in terms of evaluating common and contradictory interests realistically [26].Understanding perspectives also strengthens relations with the other person. For all these reasons, constructive resolution does not seem likely without empathy in conflict resolution process. Results of this study also support this view. The relevant literature also emphasizes the relationship between conflict resolution behaviors and strategies and empathy $[1,7,38$, 52]. Therefore, it may be stated that it is necessary to improve the empathy skill in studies and practices aiming to bring in constructive conflict resolution skills.

This study found that self-efficacy perceptions predicted conflict resolution skills in adolescents. Accordingly, it may be said that adolescents are able to solve conflicts constructively when they believe that they can solve their own conflicts. Additionally, when empathic tendency is added to the model while predicting conflict resolution skills of adolescents, their self-efficacy perceptions cease to be a significant predictor. The analysis made at this point determined that empathic tendency has a full mediation role in the relationship between conflict resolution skills and self-efficacy perceptions. Accordingly, it may be stated that adolescents who see themselves as self-efficient make effort to solve their conflicts constructively by empathizing more in their interpersonal relationships. In the relevant literature, Vera et al. found that self-efficacy predicted conflict resolution styles of adolescents significantly [51]. Similarly, studies of Syna Desivilya and Eizen revealed that self-efficacy predicted conflict resolution styles significantly [44]. However, Animasahun found that self-efficacy alone did not predict conflict resolution behaviors [2]. It is thought that adolescents may solve their conflicts in more constructive ways as their self-efficacy perception raises. According to results of this study, since the level of empathic tendency has a mediating role in the relationship between self-efficacy perceptions and conflict resolution skills, it may be stated that adolescents who see themselves as self-efficient make effort to solve their conflicts constructively by empathizing more in their interpersonal relationships.

This study found that self-regulation is a significant 
predictor in the prediction of conflict resolution skills of adolescents. It may be said that adolescents are able to solve their conflicts in constructive ways when they are able to control their emotions and behaviors and take responsibility of their emotions and behaviors. Self-regulation skills are seen influential in interpersonal relationships and conflict resolutions processes as well as in many areas of life. Similarly, Harma found that domestic conflicts were also predictors of adolescents' self-regulation skills [24].It is seen that when adolescents gain the ability to control their emotions and behaviors, they can make important contributions to the resolution of their conflicts without the supervision and observation of an adult.

Laursen, Finkstein and Betts, in their developmental meta-analysis study on the solutions used by adolescents in peer conflicts, found that settling, forcing, pressure and withdrawal strategies are the most used strategies. Although adolescents state that they mostly use settling strategy, this is generally a strategy chosen in hypothetical situations [35]. It is seen that adolescents mostly use forcing strategy in conflicts in real life. Use of forcing strategy in peer relationships may prevent adolescents from reaching their desires and objectives and from developing constructive and positive relationships with their peers. Therefore, it is thought that having constructive conflict resolution skills and using such skills in daily life as an adolescent is a must for his/her social and emotional development. This study found that empathy had a key role in the prediction of conflict resolution skills of adolescents. Empathic tendency is an important element of communication and necessary for conflict resolution skills. Therefore, studies made by psychological counselors to raise empathy skills are also important for bringing in constructive and peaceful conflict resolution skills. Additionally, one of the results of this study shows that adolescents who perceive themselves as self-efficient and can control their emotions and behaviors are able to solve their conflicts in more constructive ways. Therefore, it is believed that the inclusion of studies on self-efficacy perceptions and self-regulation skills of adolescents in practices in schools is of importance.

This study examined empathic tendency, self-efficacy perceptions and self-regulation skills as the predictor variable. The inclusion of other variables predicting conflict resolution skills of adolescents in future studies will contribute to the enrichment of the literature. This study examined general self-efficacy perception. Specifically, it is suggested to examine the extent to which social self-efficacy perception predicts conflict resolution skills.

\section{Acknowledgements}

We are very grateful to experts for their appropriate and constructive suggestions to improve this template.

\section{REFERENCES}

[1] Alexander, K.L. (2000). Prosocial behaviors of adolescents in work and family life: empathy and conflict resolution strategies with parents and peers. Doctoral Thesis, The Ohio State University. (UMI Number 9982514).

[2] Animasahun, R. A. (2008). Predictive estimates of emotional intelligence, spiritual intelligence, self-efficacy and creativity skills on conflict resolution behaviour among the NURTW in the south-western Nigeria Pakistan Journal of Life and Social Sciences, 6, 68-74.

[3] Arslan, C. (2005). Kişilerarası çatışma çözme ve problem çözme yaklaşımlarının yükleme karmaşıklığı açısından incelenmesi (Doctoral dissertation, Selçuk Üniversitesi Sosyal Bilimler Enstitüsü).

[4] Balkıs, M., Erdinç, D., \& Buluş, M. (2005). Șiddete yönelik tutumların özyeterlik medya şiddete yönelik inanç arkadaş grubu ve okula bağlılık duygusu ile ilişkisi. Ege Eğitim Dergisi, 6(2), 81-97.

[5] Bandura, A. (1997). Self-Efficacy: The Exercise of Control. New York: Freeman.

[6] Basım, H. N., Çetin, F., \& Tabak, A. (2009). Beş Faktör Kişilik Özelliklerinin Kişilerarası Çatışma Çözme Yaklaşımlarıyla İlişkisi. Turk Psikoloji Dergisi, 24(63), 20-34.

[7] Björkqvist, K., Österman, K., \& Kaukiainen, A. (2000). Social intelligence - empathy $=$ aggression?. Aggression and violent behavior, 5(2), 191-200.

[8] Bodine, J.R., Crawford, K.D., Schrumpf, F. (2002). Creating the Peaceable School: A Comprehensive Program for Teaching Conflict Resolution. Ilionois: Research Pres.

[9] Bozoğlan, B. (2014). Çatışmanın yordayıcısı olarak sosyal destek ve yaşam doyumu. Kastamonu Eğitim Dergisi, 22 (1), 161-175.

[10] Büyüköztürk, Ş. (2005). Sosyal bilimler için veri analizi el kitabı. Ankara: Pegem Akademi

[11] Büyüköztürk, Ş., Çakmak, E. K., Akgün, Ö. E., Karadeniz, Ş., \& Demirel, F. (2017). Bilimsel araştırma yöntemleri. Ankara: Pegem Akademi

[12] Büyükşahin Çevik, G. (2017). Üniversite Öğrencilerinin Toplumsal Cinsiyet Rolleri Ve Çatışma Çözme Stillerinin İncelenmesi. Mersin Üniversitesi Eğitim Fakültesi Dergisi, 13(3), 1017-1034

[13] Can, A. (2017). SPSS ile bilimsel araştırma sürecinde nicel veri analizi. Ankara: Pegem Akademi

[14] Çalıkoğlu, T. (2010). Lise öğrenimine devam eden ailesinin yanında yaşayan öğrencilerle, yetiştirme yurdunda yasayan öğrencilerin çatışma çözme davranışı ile öfke ifade stillerinin karşılaştırılması (Yüksek lisans tezi). Maltepe Üniversitesi, İstanbul. 
[15] Deutsch, M. (2005). Cooperation and Conflict A Personal Perspective on the History of The Social Psychological Study of Conflict Resolution. West, M.A, Tjosvold, D., Smith, K.G. (ED). The Essentials of Teamworking: International Perspectives.1-36. New Jersey: John Wiley \& Sons

[16] Dökmen., Ü. (1996). Sanatta ve Günlük Yaşamda İletişim Çatışmaları ve Empati. İstanbul: Sistem

[17] Eisenberg, N., Fabes, R. A., Shepard, S. A., Murphy, B. C., Guthrie, I. K., Jones, S., ... \& Maszk, P. (1997). Contemporaneous and longitudinal prediction of children's social functioning from regulation and emotionality. Child development, 68(4), 642-664.

[18] Eisenberg, N., Smith, C. L., Sadovsky, A., \& Spinrad, T. L. (2004). Effortful control: Relations with emotion regulation, adjustment, and socialization in childhood. In R. F. Baumeister \& K. D. Vohs (Eds.), Handbook of self-regulation: Research, theory, and applications (pp. 259-282). New York: Guilford.

[19] Erikson, E. H. (1984). İnsanın sekiz çağı (T. B Üstün \& V. Şar, Trans.). Ankara, Turkey: Birey ve Toplum Yayınları.

[20] Erözkan, A. (2009). Lise öğrencilerinde kişilerarası ilişki tarzlarının yordayıcıları. Selçuk Üniversitesi Sosyal Bilimler Enstitüsü Dergisi, (21), 543-551.

[21] Fırıncı Kodaz, A. (2010). İnegöl Mesleki Eğitim Merkezi öğrencilerinin sosyal becerilerine göre çatışma çözme becerilerinin incelenmesi. Yüksek Lisans Tezi, Ankara Üniversitesi Eğitim Bilimleri Enstitüsü.

[22] Gander, M. Gardiner. H. (1998). Çocuk ve Ergen Gelişimi. (Çeviren: Bekir Onur), Ankara.

[23] Gündoğdu, R. (2010). 9 Sinıf Öğrencilerinin Çatışma Çözme Öfke Ve Saldırganlık Düzeylerinin Bazı Değişkenler Açısından incelenmesi. Çukurova Üniversitesi Sosyal Bilimler Enstitüsü Dergisi, 19(3), 257-276.

[24] Harma, M. (2008). Ana-baba kontrol davranışlarının ve aile içi çatışmanın ergenlerin öz-denetim becerileri ve uyumları üzerindeki etkileri. Yüksek Lisans Tezi. Orta Doğu Teknik Üniversitesi Sosyal Bilimler Enstitüsü, Ankara.

[25] Johnson, W.D, Johnson, T.R. (1996). Conflict Resolution and Peer Mediation Programs in Elementary and Secondary Schools: A Review of the Research. Review of Educational Research, 66 (4), 459- 506.

[26] Johnson, W.D., Johnson, T.R. (1995). Teaching Students To Be Peacemakers. Edina, MN: Interaction Book Co.

[27] Johnson, W.D., Johnson, T.R. (2004). Implementing the "Teaching Students To Be Peacemakers Program". Theory Into Practice, 43 (1), 69- 79.

[28] Jones, S.T. (2004). Conflict Resolution Education: The Field, The Findings and The Future. Conflict Resolution Quarterly. 22 (1-2). 13-15.

[29] Jose, P. E. (2003). MedGraph-I: A programme to graphically depict mediation among three variables: The internet version, version 2.0. Victoria University of Wellington, Wellington, New Zealand. Retrieved from http://www.victoria.ac.nz/staff/paul-josefiles/medgraph/me dgraph.php.
[30] Kaya, A., \& Siyez, D. M. (2010). KA-Sİ çocuk ve ergenler için empatik eğilim ölçeği: Geliştirilmesi geçerlik ve güvenirlik çalışması. Eğitim ve Bilim, 35(156), 110-125.

[31] Kopp, C. B. (1982). Antecedents of self-regulation: a developmental perspective. Developmental psychology, 18(2), 199-214.

[32] Korkut, F. (2004). Okul Temelli Önleyici Rehberlik ve Psikolojik Danışma. Ankara: Anı

[33] Lane, P., McWhirter, S. \& Jeffries, J. (1992). A peer mediation model: conflict resolution for elementary and middle school children. Elementary School Guidance and Counseling, 27(1), 15-24.

[34] Lane-Garon, S.P. (2000). Practicing Peace: The İmpact Of A School-Based Conflict Resolution Program On Elementary Students. Peace and Change, 25(4), 467- 482.

[35] Laursen, B., Finkelstein, B. D., \& Betts, N. T. (2001). A developmental meta-analysis of peer conflict resolution. Developmental Review, 21(4), 423-449.

[36] Luszczynska, A., Gutierrez-Dona, B., Schwarzer, R. (2005). General Self-Efficacy in Various Domains of Human Functioning: Evidence from Five Countries. International Journal of Psychology, 40 (2), 80-89.

[37] Mischel, W., DeSmet, A.L., \& Kross, E. (2006). Self-regulation in the service of conflict resolution. . The handbook of conflict resolution: Theory and practice, 294-314.

[38] Rehber, E., \& Atıc1, M. (2009). İlköğretim ikinci kademe ögrencilerinin empatik eğilim düzeylerine göre çatışma çözme davranışlarının incelenmesi. Çukurova Üniversitesi Sosyal Bilimler Enstitüsü Dergisi, 18(1).323-342.

[39] Sandy, S. V. (2006). The development of conflict resolution skills: preschool to adulthood. The handbook of conflict resolution: Theory and practice, 356-388. New Jersey: John Wiley \& Sons

[40] Sardoğan, M.E., Karahan, T.F. (2015). Kişilik gelişimi (içinde Eğitim Psikolojisi, Kaya, A, Edt.) Ankara: Pegem Akademi

[41] Schrumpf, F., Crawford, D. K., \& Bodine, R. J. (2007). Okulda çatışma çözme ve akran arabuluculuk program rehberi. Akbalık GF, Karaduman DB, Çevirenler. Ankara: İmge Kitabevi Yayınları.

[42] Schunk, D. H., \& Pajares, F. (2009). Self-efficacy theory. Handbook of motivation at school, 35-53.

[43] Schunk, D., Meece, J. (2005). Self-Efficacy Development in Adolescences. Self-Efficacy Beliefs of Adolescents. 7196. Information Age Publishing.

[44] Syna Desivilya, H., \& Eizen, D. (2005). Conflict management in work teams: The role of social self-efficacy and group identification. International Journal of Conflict Management, 16(2), 183-208.

[45] Şahin, N. H., Basim, H. N., \& Çetin, F. (2009). Kişilerarası Çatişma Çözme Yaklaşımlarında Kendilik Algısı ve Kontrol Odağı. Turk Psikiyatri Dergisi, 20(2), 153-163.

[46] Taştan, N. (2004). Çatışma Çözme ve Akran Arabuluculuğu Eğitimi Programlarının İlköğretim Altıncı Sınıf 
Öğrencilerinin Çatışma Çözme ve Akran Arabuluculuğu Becerilerine Etkisi. Yayınlanmamış Doktora Tezi. Ankara: Ankara Üniversitesi Eğitim Bilimleri Enstitüsü.

[47] Telef, B. B. (2011). Öz-yeterlikleri farklı ergenlerin psikolojik semptomlarını incelenmesi (Doctoral dissertation, DEÜ Eğitim Bilimleri Enstitüsü).

[48] Tercanlı Metin, G. (2013). Düşük sosyo-ekonomik düzeye sahip ergenlerde olumsuz yaşam olayları ve duygusal-davranışsal uyum ilişkisinde özdenetimin aracı rolü. Yayınlanmamış yüksek lisans tezi, İstanbul Üniversitesi Sağlık Bilimleri Enstitüsü.

[49] Türnüklü, A. (2006). Sınıf ve Okul Disiplinine Çağdaş Bir
Yaklaşım: Onarıcı Disiplin. Ankara: Ekinoks

[50] Türnüklü, A., Kaçmaz, T., İkiz, E., \& Balcı, F. (2009). Liselerde öğrenci şiddetinin önlenmesi: Anlaşmazlık çözümü, müzakere ve akran-arabuluculuk eğitim programı. Ankara: Maya Akademi.

[51] Vera, E. M., Shin, R. Q., Montgomery, G. P., Mildner, C., \& Speight, S. L. (2004). Conflict resolution styles, self-efficacy, self-control, and future orientation of urban adolescents. Professional School Counseling, 16 (2), 183-208.

[52] Wied, M., Branje, J.T.S., Meeus, H.J.W. (2007). Empathy and Conflict Resolution in Friendship Relations among Adolescents. Aggressive Behavior, 33, 48- 55. 